\section{PENERAPAN KLAUSULA BAKU PADA PERJANJIAN GADAI PADA PT. PEGADAIAN (PERSERO) $^{1}$}

Oleh: Sartika Anggriani Djaman ${ }^{2}$

\begin{abstract}
ABSTRAK
Tujuan dilakukannya penelitian ini adalah untuk mengetahui tentang penerapan klausula baku dalam perjanjian gadai dan hak dan kewajiban kreditur dan debitur. Dengan metode penelitian hukum normatif disimpulkan bahwa: 1. Pembuatan klausula baku pada perjanjian gadai pada PT Pegadaian kurang melindungi kepentingan hukum nasabah. Hal ini disebabkan karena isi perjanjian memuat syarat perjanjian, asas kebebasan berkontrak, serta hak dan kewajiban para pihak yang tidak proporsional, sehingga secara yuridis normatif menyimpang dari prinsip-prinsip umum perjanjian yang seharusnya berlaku. 2. PT Pegadaian sepenuhnya bertanggung jawab jika terjadi wanprestasi dan terdapat kesalahan yang terkait dengan kerusakan atau kerugian nasabah yang disebabkan kekalaian pihak Pegadaian, sedangkan bila terjadi kesalahan menaksir dan lelang barang gadai (tanpa diketahui pemiliknya) kurang bertanggung jawab. Hal tersebut terjadi karena tidak ada atau belum adanya komplain dari nasabah. Sedangkan pihak debitur/nasabah melakukan wanprestasinya dalam bentuk tidak membayar pinjaman setelah jatuh tempo, maka sudah selayaknya untuk menerima semua konsekuensi perjanjian yang lebih banyak dalam bentuk risiko lelang barang gadai.

Kata kunci: perjanjian baku, gadai
\end{abstract}

\section{PENDAHULUAN}

Pada dasarnya bahwa hukum perjanjian dalam KUH Perdata mengandung ketentuan-ketentuan yang memaksa

\footnotetext{
${ }^{1}$ Artikel skripsi.

${ }^{2}$ NIM: 090711473.
}

(dwingen, mandatory) dan yang opsional (aanvullend, optional) sifatnya. Untuk ketentuan-ketentuan yang memaksa, para pihak tidak mungkin menyimpanginya dengan membuat syarat-syarat dan ketentuan-ketentuan lain dalam perjanjian yang mereka buat. Namun terhadap ketentuan-ketentuan undang-undang yang bersifat opsional, para pihak bebas menyimpanginya dengan mengadakan sendiri syarat-syarat dan ketentuanketentuan lain sesuai dengan kehendak para pihak. Maksud dari adanya ketentuanketentuan yang opsional itu, adalah hanya untuk memberikan aturan yang berlaku bagi perjanjian yang dibuat oleh para pihak bila memang para pihak belum mengatur atau tidak mengatur secara tersendiri agar tidak terjadi kekosongan pengaturan mengenai hal atau materi yang dimaksud. ${ }^{1}$

Asas kebebasan berkontrak diatur dalam Pasal 1338 KUH Perdata yang pada pokoknya mengatur bahwa "Semua persetujuan yang dibuat secara sah berlaku sebagai Undang-undang bagi mereka yang membuatnya".

Kehadiran kontrak baku telah menjadi sorotan oleh berbagai kalangan ahli hukum, dan sorotan tersebut dapat dipahami sebagai suatu upaya menjadikan kontrak standar sebagai suatu masalah baru yang menjadi sumber konflik kepentingan para pihak dalam suatu perjanjian sampai akhirakhir ini banyak dipersoalkan masyarakat. Ternyata dalam prakteknya kontrak standar kurang memberikan keuntungan salah satu pihak dalam pelaksanaan perjanjian. Kontrak bisnis yang pada umumnya berbentuk standar senantiasa terkesan sebagai kontrak yang tidak seimbang, karena hanya menguntungkan salah satu pihak, dalam kontrak standar berhadapan dua kekuatan yang tidak seimbang antara

\footnotetext{
${ }^{1}$ Sutan Remy Sjahdeini, Kebebasan Berkontrak Dan Perlindungan Yang Seimbang bagi Para Pihak Dalam Perjanjian Kredit Bank Di Indonesia, Institut Bankir Indonesia,1993, hal.47.
} 
pihak yang mempunyai bargaining position yang kuat dengan pihak yang lemah bargaining position-nya. Pihak yang posisinya lemah hanya sekedar menerima segala isi kontrak yang standar dengan terpaksa. Bilamana ia mencoba menawar dengan alternatif lain, kemungkinan besar akan menerima konsekuensi kehilangan apa yang dibutuhkan.

Keberadaan PT Pegadaian sebagai salah satu lembaga perkreditan non bank dengan mottonya "Mengatasi Masalah Tanpa Masalah", merupakan jalan keluar bagi masyarakat golongan ekonomi lemah sebagai alternatif penyaluran uang pinjaman dalam waktu singkat, yang tidak mungkin dilakukan bila mengambil kredit dari bank dengan perjanjian Gadai atau Pand. Dalam perjanjian gadai ini, masyarakat dapat memperoleh dana dalam jumlah yang disesuaikan dengan agunan barang yang ditaksir untuk menentukan berapa dana yang akan diperoleh sesuai dengan peraturan dan ketentuan perjanjian.

Perseroan Terbatas (PT) Pegadaian adalah "Badan Usaha Milik Negara yang mengemban misi untuk menyediakan pelayanan bagi kemanfaatan umum dan sekaligus memupuk keuntungan berdasarkan prinsip pengelolaan perusahaan, penyaluran uang pinjaman kepada masyarakat ini didasarkan hukum gadai". ${ }^{3}$ PT Pegadaian menyalurkan dana pinjaman kepada setiap debiturnya untuk memperoleh kredit jika ada jaminan berupa benda bergerak.

Perjanjian Gadai adalah satu bentuk perjanjian khusus yang tunduk pada ketentuan Buku III KUH Perdata. Sumber hukum utama gadai adalah perjanjian pinjam meminjam berupa sejumlah uang, yang diatur dalam Pasal 1754 sampai Pasal

\footnotetext{
${ }^{3}$ Mariam Darus Badrulzaman, Aneka Hukum Bisnis,, Cet.1.Ed.1, Bandung: Alumni, 1994, hal. 28
}

1773 KUH Perdata. Menurut ketentuan Pasal 1754 KUH Perdata : "Pinjam meminjam ialah perjanjian dengan mana pihak yang satu memberikan kepada pihak yang lain suatu jumlah tertentu barangbarang yang menghabis karena pemakaian, dengan syarat bahwa pihak yang belakangan ini akan mengembalikan sejumlah yang sama dari macam dan keadaan yang sama pula.". Selain itu, Keputusan Direksi PT Pegadaian Nomor : 1095/SDM.200322/2004 tanggal 28 April 2004 tentang Struktur Organisasi Dan Tata Kerja PT Pegadaian sebagai tindak lanjut peraturan sebelumnya, yaitu Keputusan Direksi PT Pegadaian tanggal 17 Juni 2003 No.21/KP.4000324/2002 tentang Organisasi dan Pedoman Kerja PT Pegadaian.

Berdasarkan fenomena tersebut, untuk mendukung motto PT Pegadaian yaitu "Mengatasi Masalah Tanpa Masalah", maka issu yang perlu diteliti dan dikaji lebih lanjut adalah untuk mengetahui secara mendalam dampak klausul baku yang dibebankan kepada nasabahnya. Untuk itu penulis akan meneliti lebih lanjut dalam Skripsi dengan judul : "Penerapan Klausula Baku pada Perjanjian Gadai pada PT Pegadaian (PERSERO)".

\section{PEMBAHASAN}

\section{A. Penerapan Klausula Baku Dalam Perjanjian Gadai}

Dalam perjanjian gadai pada PT Pegadaian digunakan klausula baku sebagai dasar perjanjian dalam pemberian dana kepada nasabah. Dari sisi hukum perjanjian, klausula baku yang dibuat PT pegadaian merupakan salah satu bentuk perjanjian yang sah jika pihak Kreditur dan Debitur menjadikan kesepakatan sebagai instrumen hukum dalam pemenuhan hak dan kewajiban para pihak. Anggapan tersebut sesuai Pasal 1320 KUH Perdata yang mensyaratkan adanya kesepakatan para pihak. Pengertian sepakat secara hipotetis 
dikatakan bahwa para pihak tidak di bawah tekanan (tekanan psikologis dan tekanan ekonomi) yang mengakibatkan "cacad" hukum. Kesepakatan yang dilahirkan adalah kesepakatan "semu", yaitu kesepakatan di bawah tekanan salah satu pihak (biasanya debitur) yang merupakan perwujudan penggunaan klausula baku. Dengan klausula baku dikehendaki tercapainya tujuan hukum yaitu keadilan dan perlindungan para pihak dalam perjanjian. Oleh karena itu, untuk mengetahui apakah klausula baku yang dibuat PT Pegadaian dalam perjanjian gadai dengan nasabah yang memuat isi perjanjian tentang kesepakatan yang dikehendaki telah disetujui (overeenstemende).

Tujuan utama yang ingin dicapai para pihak dalam kesepakatan dalam hukum bertujuan untuk melindungi kepentingan para pihak dalam pelaksanaan perjanjian. Instrumen hukum perjanjian yang lahir karena kesepakatan, merupakan salah satu bentuk perjanjian yang dapat menjadi tumpuan para pihak dalam mencapai tujuan dan kepentingan masing-masing.

Perjanjian gadai dapat dilakukan dalam bentuk perjanjian tertulis, sebagaimana halnya dengan perjanjian pokoknya, yaitu perjanjian pemberian kredit. Perjanjian tertulis ini dapat dilakukan dalam bentuk akta di bawah tangan dan akta otentik. Di dalam prakteknya, perjanjian gadai ini dilakukan dalam bentuk akta di bawah tangan yang ditandatangani oleh pemberi gadai dan penerima gadai. Bentuk, isi dan syarat-syaratnya telah ditentukan oleh PT Pegadaian secara sepihak.

Persyaratan yang tercantum dalam Surat Bukti Kredit telah distandarisasi oleh PT Pegadaian. Pemberi gadai tinggal menyetujui atau tidak menyetujui persyaratan tersebut. Apabila pemberi gadai menyetujuinya, ia menandatangani syarat tersebut. Apabila tidak disetujuinya, ia tidak akan menandatangani dan perjanjian gadai itu tidak ada.
Dalam perjanjian gadai, PT Pegadaian menggunakan klausula baku sebagai instrumen hukum perjanjian yang berlaku bagi para pihak. Berlakunya klausula baku dalam pelaksanaannya, diasumsikan telah menempatkan posisi nasabahnya tidak sama dalam implementasinya. Oleh karena itu, dalam sub bab ini akan dianalisis instrumen hukum perjanjian yang digunakan PT Pegadaian dalam bentuk Surat Bukti Kredit selanjutnya disebut SBK, yang memuat beberapa aspek hukum untuk menemukan ada tidaknya perlindungan hukum bagi nasabah dalam perjanjian gadai. Beberapa aspek dimaksud adalah :

1. syarat-syarat perjanjian;

2. asas kebebasan berkontrak;

Untuk mengetahui beberapa aspek hukum yang menjadi dasar hipotesis tersebut akan dianalisis pada pembahasan selanjutnya.

1. Syarat-syarat Perjanjian

Dalam hukum perjanjian ditetapkan adanya beberapa syarat terbentuknya suatu perjanjian. KUH Perdata sebagai dasar acuan hukum perjanjian menetapkan beberapa syarat formal dari suatu perjanjian dapat mengikat para pihak. Salah satu syarat yang sangat menentukan adalah penandatangan kredit sebagai wujud adanya kesepakatan sebagaimana diatur dalam Pasal 1320 KUH Perdata.

Dalam perjanjian kredit aspek yang menentukan adalah dilakukannya penandatangan perjanjian kredit. Penandatanganan perjanjian kredit dari aspek hukum perjanjian menunjukkan adanya persetujuan para pihak. Dalam acuan teoritis dihipotesiskan bahwa esensi kehendak yang terwujud dalam bentuk panandatanganan kredit para pihak dalam perjanjian sebagai bukti bahwa keduanya telah sepakat melaksanakan semua isi perjanjian dengan segala resiko dan konsekuensinya. 
Terwujudnya kesepakatan diketahui dari terbitnya bukti tertulis (dalam hal ini Surat Bukti Kredit selanjutnya disebut SBK). Disepakatinya surat perjanjian dalam bentuk tertulis, diartikan sebagai suatu wujud kesepakatan yang sesuai dengan acuan teoritis tentang persesuaian kehendak. Penandatangan berarti sama dengan penerimaan atau acceptatie. Konsekuensi yuridisnya adalah pihak yang menandatangani telah menyetujui semua isi perjanjian. Hal tersebut juga dapat dirujuk pada pasal 1233 KUH Perdata "Tiaptiap perikatan dilahirkan baik karena persetujuan, baik karena undang-undang". Selain itu kekuatan hukum persetujuan adalah ditunjukkan adanya indikator seseorang mengikatkan diri kepada orang lain (Pasal 1313 KUH Perdata : "Suatu perjanjian adalah suatu perbuatan dengan mana satu orang atau lebih mengikatkan dirinya terhadap satu orang lain atau lebih").

Penandatanganan suatu perjanjian secara teknis-yuridis merupakan salah satu bentuk yang utuh dari suatu perjanjian. Terbentuknya suatu perjanjian sebagai suatu kesepakatan, secara teoritik masih perlu diuji dari syarat-syarat perjanjian yang secara yuridis menjadi parameter umum bagi semua bentuk perjanjian yang diatur secara tegas dalam Pasal $1320 \mathrm{KUH}$ Perdata. Pasal tersebut merupakan pasal yang mencantumkan secara limitatif beberapa syarat yang harus dipenuhi agar suatu perjanjian (terutama perjanjian yang terbentuk karena kesepakatan) dinyatakan sah secara yuridis. Adapun syarat-syarat yuridis dimaksud adalah :

a. sepakat mereka yang mengikatkan dirinya;

b. kecakapan untuk membuat suatu perikatan;

c. suatu hal tertentu;

d. suatu sebab yang halal.

Meskipun demikian tujuan
penandatanganan nasabah hanya untuk

memenuhi tuntutan sesaat, yaitu mendapatkan uang pinjaman. Menurut Joko Purnomo, hal itu dapat terjadi oleh karena:

1. nasabah sudah sangat mendesak mendapatkan uang, sehingga tidak sempat lagi membaca isi perjanjian;

2. pihak pegadaian menyesuaikan permintaan pinjaman dengan jenis barang gadai yang dijaminkan oleh pihak nasabah;

3. sifat kebakuan perjanjian yang sulit diubah lagi sudah dalam bentuk yang baku. $^{1}$

Konsekwensi yuridisnya bahwa dengan mengetahui prinsip asas kebebasan berkontrak menjadi indikasi bahwa nasabah tidak mempersoalkan keberadaan syarat-syarat baku dalam perjanjian (SBK). Itulah sebabnya sehingga tingkat penerimaan akan semua isi perjanjian (syarat-syarat baku) tidak menjadi penghalang terbentuknya perjanjian gadai; nasabah lebih mengutamakan pada kebutuhan mendapatkan dana (pinjaman) meskipun kurang sesuai dengan prinsipprinsip perjanjian yang diketahuinya. Dapat dipahami bahwa secara yuridis-teoritik perjanjian yang dibuat oleh PT Pegadaian meskipun menyimpang dari prinsip asas kebebasan berkontrak, namun pihak nasabah tidak menjadikannya sebagai suatu masalah hukum yang harus dijadikan dasar gugatan secara litigasi, sebab responden mengetahui secara utuh isi perjanjian yang diberikan oleh PT pegadaian. Apapun yang dicantumkan dalam perjanjian yang dibuat PT Pegadaian (SBK atau kebijakan) dapat dipastikan akan disetujui nasabah. Tingginya persetujuan tersebut sangat terkait dengan faktor motivasi nasabah ke Pegadaian. Selain itu, mudahnya proses peminjaman, barang gadai dan cepatnya

\footnotetext{
1 Joko Purnomo, Wawancara Pribadi, Nasabah Perum Pegadaian Sario cabang Manado, tanggal 15 Mei 2009
} 
nasabah mendapatkan uang pinjaman menjadi faktor pemicu nasabah mengenyampingkan syarat-syarat baku sebagai dasar perjanjian. Posisi mendesak nasabah (butuh uang) menjadi penyebab utama sehingga nasabah menyepakati semua syarat-syarat baku. Itulah sebabnya sehingga banyak nasabah golongan ekonomi menengah ke bawah mendatangi PT Pegadaian. Adanya pernyataan tersebut dapat dikemukakan bahwa frekuensi peminjaman dan penebusan barang gadai dan yang tidak dapat ditebus melalui PT Pegadaian perkembangannya cukup baik. Selain itu, dari sisi hukum kemampuan meminjam dan menebus barang gadai proporsinya hampir seimbang. Artinya, modal yang dipinjamkan dengan yang dikembalikan sirkulasinya tidak mengalami kemacetan. Oleh karena itu, data tersebut memberikan informasi bahwa nasabah sangat banyak berhubungan dengan PT Pegadaian dan kecepatan proses peminjaman dan pengembalian tidak menjadi masalah bagi nasabah, termasuk penggunaan syarat-syarat baku.

\section{B. Hak dan kewajiban Kreditur dan Debitur}

Pemenuhan hak dan kewajiban para pihak dalam hukum perjanjian dijamin oleh undang-undang. Pengaturan tentang hak dan kewajiban kreditur dan debitar dalam perjanjian mencerminkan sejumlah asas yang menjadi prinsip-prinsip atau asas-asas perjanjian. Dalam terminologi hukum, hak dan kewajiban merupakan sesuatu yang seharusnya diterima atau dilaksanakan atas suatu objek yang diperjanjikan. Objek perjanjian dalam hukum perikatan merupakan sesuatu yang menjadi tujuan para pihak. Pelaksanaan hak dan kewajiban dalam hukum perikatan disebut prestasi. Oleh karena itu, jika dikaitkan dengan perjanjian gadai, maka nasabah dengan perjanjian bersyarat baku dari Pegadaian berstatus sebagai debitur (mengikatkan diri dalam perjanjian) sedangkan PT Pegadaian memposisikan diri sebagai kreditur (pembuat isi perjanjian) yang harus menjadi prestasi dari debitur sebagai pembuat janji (promise). Dengan demikian, kewajiban nasabah adalah kewajiban debitur untuk mengikuti semua isi perjanjian SBK. Oleh karena itu, untuk mengetahui apakah nasabah mengetahui semua isi perjanjian (SBK), maka diperlukan tanggapan empirik apakah nasabah mengetahui semua isi perjanjian yang menjadi sumber hak kreditur (janji dari debitur). Perlunya pengetahuan maksud isi perjanjian sangat penting, karena keterpaksaan nasabah menandatangani isi perjanjian dapat terkait dengan sejauh mana mengetahui semua maksud isi perjanjian gadai. Dikatakan bahwa semakin banyak pengetahuan terhadap isi perjanjian akan semakin tinggi ketidak setujuannya atau persetujuannya terhadap semua maksud isi perjanjian. Selain itu, secara teoritik pengetahuan akan maksud isi perjanjian menjadi sumber kekuatan sah tidaknya suatu perjanjian.

Berdasarkan uraian tersebut tampak dengan jelas bahwa pengaturan hak dan kewajiban nasabah memiliki proporsi yang berbeda sehingga apa yang menjadi kewajiban nasabah diatur secara rinci dalam perjanjian, sedangkan kewajiban kreditur kurang tampak dalam perjanjian kredit (SBK).

\section{Tanggung Jawab Nasabah Dan PT Pegadaian}

Dalam hukum perjanjian tangung jawab para pihak secara teoritis menjadi tuntutan hukum yang harus ditegakkan dalam pelaksanaan perjanjian. Kedua belah pihak telah sepakat melaksanakan perjanjian dengan ditandai pembubuhan tanda tangan. Tanda tangan merupakan salah satu bukti bahwa para pihak telah mengetahui dan bersedia melaksanakan isi perjanjian (prestasi) sesuai dengan hak dan kewajiban para pihak dengan penuh tanggung jawab. Dalam Surat Bukti Perjanjian (SBK) PT Pegadaian dengan 
nasabah sepakat menjadikan syarat-syarat baku sebagai acuan pelaksanaan perjanjian. Isi perjanjian di dalamnya memuat beberapa syarat baku yang dalam kenyataannya lebih banyak memberikan ruang (power) kepada PT Pegadaian. Pada prinsipnya semua isi perjanjian memuat tanggung jawab.

Untuk mengetahui seberapa besar tanggung jawab nasabah dan PT Pegadaian dalam perjanjian baku yang memuat syaratsyarat baku akan dikaji dari beberapa acuan teoritis. Acuan teoritis yang digunakan menganalisis tanggungjawabnya adalah:

a. penggunaan konsep wanprestasi;

b. penggunaan konsep force majeur; dan

c. menilai kesalahan PT Pegadaian dalam proses penaksiran, penetapan bunga modal dan lelang barang gadai nasabah.

Ketiga aspek yuridis-konseptual akan dikemukakan pada pembahasan selanjutnya.

\section{Wanprestasi}

Lelang barang agunan nasabah merupakan suatu syarat baku yang dapat diberlakukan ketika nasabah tidak mengembalikan dana pinjaman sesuai dengan masa pengembalian (jatuh tempo). Pelaksanaan lelang barang gadai merupakan perwujudan dari pihak nasabah melalaikan prestasi yang menjadi kewajibannya. Tidak terlaksananya kewajiban nasabah lazim pula disebut sebagai wanprestasi.

Dalam terminologi hukum perjanjian seseorang dinyatakan telah melakukan wanprestasi atau berprestasi buruk (breach of contract) apabila:

(a) nasabah tidak melakukan sesuatu perbuatan tepat pada waktunya;

(b) terlambat melakukan sesuatu yang seharusnya dilakukan; dan

(c) berbuat sesuatu yang seharusnya tidak boleh dilakukannya.

Dalam perjanjian gadai masalah wanprestasi merupakan suatu hal yang dapat terjadi bagi para pihak sehingga wanprestasi dapat berlaku bagi debitur dan kreditur. Selain itu, wanprestasi terkait dengan resiko yang harus ditanggung oleh masing-masing pihak atas perjanjian yang telah disepakati. Resiko yang dimaksud adalah jika nasabah lalai melaksanakan kewajibannya

(wanprestasi) mengembalikan dana pinjaman sesuai dengan masa pinjaman selama 120 hari pada semua kategori pinjaman, maka berlaku syarat baku berupa lelang barang gadai. Pengaturan hal tersebut secara tegas ditetapkan oleh PT Pegadaian sebagai kreditur yang memberikan pinjaman guna mendapatkan kembali pinjaman yang telah masa jatuh tempo. Nasabah yang menyimpan barang gadai dikenakan biaya penyimpanan dan pemeliharaan yang besarnya sesuai dengan golongan pinjaman. Bila terjadi kehilangan, kerusakan atas barang jaminan yang disebabkan kelalaian pihak pegadaian, diberikan penggantian sebesar $125 \%$ dari nilai taksiran barang jaminan. Kebijakan perbedaan tarif menurut golongan pinjaman agar dapat melindungi masyarakat kecil dari kelompok yang mampu. Selain itu, semua barang nasabah diasuransikan untuk memberikan perlindungan barang nasabah selama dalam masa sebelum jatuh tempo. Semua syarat yang tersebut dimuat secara jelas pada halaman depan Surat Bukti Kredit atau SBK. Oleh karena itu, dengan melihat beberapa syarat baku dalam SBK tampak bahwa penetapan prosentase, golongan modal, dan sewa modal semua dibuat sepihak oleh PT Pegadaian.

Tindakan wanprestasi juga dapat dilakukan oleh Kreditur atau PT Pegadaian. Tindakan wanprestasi ini dapat berupa tertukarnya barang gadai, hilangnya barang gadai atau rusaknya barang gadai. Terhadap wanprestasi tersebut, pertanggung jawaban pegadaian didasarkan pada perjanjian gadai. 
Menurut analisis penulis, perjanjian gadai itu sendiri merupakan perjanjian baku, yang intinya bertentangan baik berdasarkan UU Nomor 8 Tahun 1999 tentang Perlindungan konsmen khususnya Pasal 18:

(1) Pelaku usaha dalam menawarkan barang dan/atau jasa yang ditujukan untuk diperdagangkan dilarang membuat dan/atau mencantumkan klausul baku pada setiap dokumen dan/atau perjanjian apabila;

a. menyatakan pengalihan tanggung jawab pelaku usaha;

b. menyatakan bahwa pelaku usaha berhak menolak menyerahkan kembali barang yang dierikan konsumen;

c. menyatakan bahwa pelaku usaha berhak menolak penyerahan kembali uang yang dibayarkan atas barang dan/atau jasa yang dibeli oleh konsumen;

d. menatakan pemberian kuasa dari konsumen kepada pelaku usaha baik secara langsung maupun tidak langsung untuk melakukan segala tindakan sepihak berkaitan denganbarangbarang yang dibeli oleh konsumen secara angsuran;

e. mengatur perihal pembuktian atas hilangnya kegunaan baran atau pemanfaatan jasa yang dibeli oleh konsumen;

f. memberi hak kepada pelaku usaha untuk mengurangi manfaat jasa atau mengurangi harta kekayaan konsumen yang menjadi objek jual beli jasa;

g. menyatakan tunduknya konsumen kepada peraturan yang berupa aturan baru, tambahan,lanjutan dan/atau pengubahan lanjutan yang dibuat sepihak oleh pelaku usaha dalam masa konsumen memanfaatkan jasa yang dibelinya; h. menyatakan bahwa konsumen memberi kuasa kepada pelaku usaha untuk pembebanan hak tanggungan, hak gadai atau hak jaminan terhadap barang yang dibeli oleh konsumen secara angsuran;

(2) Pelaku usaha dilarang mencantumkan klausula baku yang leak atau bentuknya sulit terlihat atau tidak dapat dibaca secara jelas, atau yang pengungkapannya sulit dimengerti. (3) Setiap klausula baku yang telah ditetapkan pelaku usaha pada dokumen atau perjanjian yang memenuhi ketentuan sebagaimana dimaksud pada ayat (1) an ayat (2) dinyatakan batal demi hukum.

(3) Pelaku usaha wajib menyesuaikan klausula baku yang bertentangan dengan undang-undang ini; maupun berdasarkan KUH Perdata Pasal 1320 menyangkut syarat sahnya perjanjian :

a. kesepakatan atau persetujuan kehendak para pihak;

b. kecakapan para pihak dalam membuat suatu perjanjian;

c. suatu hal tertentu;

d. suatu causa yang halal.

Mungkin lebih tepatnya, bahwa terhadap Perjanjian Kredit Dengan Jaminan Benda Bergerak secara garis besar perlu dipertanyakan menyangkut hal kesepakatan para pihak. Memang Debitur pada saat barang jaminan ditaksir diberikan perkiraan besaran pinjaman yang dapat diperoleh,tetapi apakah negosiasi ini juga dapat dikatakan suatu kesepakatan. Penulis lebih memandang bahwa tindakan tersebut lebih didasarkan kepentingan/subyektivitas dari debitur yang dinilai dan ditanggapi berdasaran kebutuhan, namun format baku dalam perjanjian gadai tetap menempatkan pegadaian dalam posisi yang berdasarkan konsekuensi haknya sangat lemah.

Berdasarkan hal tersebut, maka yang akan diukur untuk menemukan kesalahan pihak kreditur dalam perjanjian gadai, akan 
diajukan beberapa aspek empirik. Terdapat beberapa aspek empirik yang menjadi isu hukum yang dijadikan fokus penelitian guna menemukan unsur-unsur kesalahan kreditur yaitu:

a. Penetapan nilai barang gadai disesuaikan dengan suatu kriteria tertentu menurut versi pegadaian. Dasar penetapan penaksiran dimaksud merupakan sepihak dan tidak dapat digugat oleh nasabah. Itulah sebabnya sehingga dasar dan cara tersebut secara teoretik dirasakan merugikan. Sebab, pada asasnya isi suatu perjanjian secara teoritik dikehendaki atau disetujui para pihak. Isi perjanjian harus memuat dan melindungi semua kepentingan para pihak. Dalam perjanjian yang isinya memuat semua kepentingan para pihak merupakan pencerminan dari asas keseimbangan. Keseimbangan dalam perjanjian diartikan bahwa pihak kreditur dapat mempunyai kekuatan untuk menuntut prestasi dan jika tidak, maka kreditur dapat menuntutnya melalui kekayaan debitur (barang jaminan nasabah). Sebaliknya pihak debitur menuntut tanggung jawab kreditur sebagai prestasinya dengan itikad baik (te geoder throuw). Dengan demikian keseimbangan keduanya tampak dalam perjanjian dan pelaksanaannya.

b. Kesalahan dalam Lelang Barang Jaminan Nasabah. Dalam perjanjian PT Pegadaian dengan nasabah salah satu isi syarat baku adalah jika terjadi jatuh tempo masa tebusan, maka barang jaminan nasabah dilelang. Lelang barang nasabah merupakan upaya terakhir yang dilakukan pihak pegadaian. Diketahui bahwa prosedur lelang berkaitan dengan pegadaian sejak pertama mengajukan permohonan pinjaman sampai lelang gadai memiliki proses alur. Alur atau prosedur harus dilalui setiap calon nasabah sampai perjanjian atau hubungan hukum pihak pegadaian dengan nasabah.

Persoalan apakah menggunakan syarat baku atau tidak bukanlah menjadi salah satu unsur motivasi. Itulah sebabnya sehingga saat ini ada kecenderungan paradigma normatif yang terkait dengan nasabah diarahkan menggunakan undangundang perlindungan hukum konsumen yang secara nyata tidak hanya menggunakan instrumen hukum privat, tetapi melibatkan instrumen hukum publik (hukum administrasi). Sebagai usaha yang bergerak dibidang jasa pembiayaan, Pegadaian banyak menyangkut kepentingan publik (negara/pemerintah) terutama yang bersifat administratif. Oleh karena itu, kepentingan publik banyak diatur dalam berbagai peraturan perundang-undangan administrasi Negara. Instrumen hukum perlindungan konsumen (hukum administrasi) dapat menjangkau kepentingan hukum privat. Hukum perlindungan konsumen dapat melibatkan hukum publik, apalagi PT Pegadaian sebagai salah satu institusi publik dapat dijadikan sebagai salah satu pihak yang dikontrol oleh norma hukum publik dalam hal penentuan kebijakan yang terkait dengan kepentingan masyarakat banyak.

\section{PENUTUP}

\section{A. Kesimpulan}

1. Pembuatan klausula baku pada perjanjian gadai pada PT Pegadaian kurang melindungi kepentingan hukum nasabah. Hal ini disebabkan karena isi perjanjian memuat syarat perjanjian, asas kebebasan berkontrak, serta hak dan kewajiban para pihak yang tidak proporsional, sehingga secara yuridis normatif menyimpang dari prinsipprinsip umum perjanjian yang seharusnya berlaku.

2. PT Pegadaian sepenuhnya bertanggung jawab jika terjadi wanprestasi dan terdapat kesalahan yang terkait dengan 
kerusakan atau kerugian nasabah yang disebabkan kekalaian pihak Pegadaian, sedangkan bila terjadi kesalahan menaksir dan lelang barang gadai (tanpa diketahui pemiliknya) kurang bertanggung jawab. Hal tersebut terjadi karena tidak ada atau belum adanya komplain dari nasabah. Sedangkan pihak debitur/nasabah melakukan wanprestasinya dalam bentuk tidak membayar pinjaman setelah jatuh tempo, maka sudah selayaknya untuk menerima semua konsekuensi perjanjian yang lebih banyak dalam bentuk risiko lelang barang gadai.

\section{B. Saran}

Sebaiknya pihak pegadaian dalam menaksir barang gadai dapat menggunakan taksiran pembanding yang diajukan nasabah untuk menetapkan nilai barang gadai yang sesuai dengan kepentingaan para pihak. Mungkin untuk mendapatkan suatu taksiran yang optimal harus didukung oleh peralatan taksiran yang optimal pula. Sudah saatnya masalah perlindungan nasabah pegadaian menggunakan norma hukum dalam undang-undang perlindungan konsumen yang dapat menggunakan instrumen hukum privat dan norma hukum public agar kepentingan konsumen dapat terlindungi.

Hendaknya PT Pegadaian dalam membuat syarat-syarat perjanjian (dalam SBK) dengan huruf cetak yang lebih besar, supaya konsumen dapat membaca dan diketahui secara luas, karena huruf yang ada sekarang terlalu kecil, sehingga banyak debitur tidak mengetahui hak-haknya. Untuk lebih menarik lagi bagi masyarakat pencari kredit pada umumnya, hendaknya suku bunga PT Pegadaian dapat ditinjau kembali.

\section{DAFTAR PUSTAKA}

Abdulkadir Muhammad., Perjanjian Baku Dalam Praktek Perusahaan
Perdagangan, Citra Aditya Bakti, Bandung, 1992,

-----., Hukum Perikatan, Citra Aditya

Bakti, Bandung, 1992.

Ahmadi Miru dan Sutarman Yudo, Hukum Perlindungan Konsumen, RajaGrafindo Persada, Jakarta, 2005

H. Salim HS, Perkembangan Hukum Jaminan Di Indonesia, Raja Grafindo Persada, Jakarta, 2005.

Mariam Darus Badrulzaman, Aneka Hukum Bisnis, Alumni Cet.1.Ed.1, Bandung, 1994.

-----------, 1996, KUH Perdata Buku III Perikatan dan Penjelasan, Alumni Bandung.

Munir Fuady,. Hukum Bisnis Teori dan Praktek, Citra Aditya Bakti, Bandung, 1994.

Ronny Hanitijo Soemitro, S.H, Metodologi Penelitian Hukum dan Jurimeteri, Ghalia Jakarta, 1990.

Subekti R., Hukum Perikatan, Citra Aditya Bakti, Jakarta, 1992.

Sutan Remi Syahdemi, 1993, Kebebasan Berkontrak dan Perlindungan yang Seimbang Bagi Para Pihak Dalam Perjanjian Kredit Bank Indonesia, Institut Bankir Indonesia, 1993.

Peraturan Perundang-undangan

Undang-undang Nomor Nomor 8 Tahun 1999 tentang Perlindungan Konsumen.

Kitab Undang-Undang Hukum Perdata (KUH Perdata). 